\title{
INTRODUCCIÓ DE LA LLENGUA ANGLESA AL CICLE INICIAL D'EDUCACIÓ PRIMÀRIA
}

\author{
Salvador Moreno. Mestre del CEIP de Pràctiques de Tarragona
}

Aprendre una llengua estrangera facilita als infants el procés cognoscitiu i de socialització en relació a altres llengües i cultures, de manera que puguin sentirse integrats en una societat que cada vegada és més multicultural i plurilingüe.

Aquest curs s'ha iniciat la introducció de l'anglès als nens de 6 anys amb la intenció que els permeti l'adquisició d'una competència comunicativa en aquesta llengua, en diferents situacions i al mateix temps, aprofitar la motivació, la plasticitat receptiva i la gran capacitat de comunicar-se sense inhibicions, que poden servir per a fixar unes bases auditives i fonètiques útils per a l'aprenentatge de la llengua anglesa.

\section{Principis metodològics}

Els principis metodològics que s'utilitzen per a l'aprenentatge de l'anglès al Cicle Inicial segueixen els següents criteris:

- La llengua s'aprèn quan s'utilitza, per tant ha de donar resposta a un seguit d'activitats comunicatives molt variades, orientades cap a una comunicació oral.

- En aquestes edats, els nens/es adquireixen fàcilment el llenguatge per imitació, a partir dels models que se'ls ofereix: el que diu i fa el personatge d'un conte, o els intercanvis pautats d'un joc, cantar i aprendre una cançó. Aquestes activitats impliquen una capacitat d'atenció i d'anàlisi d'uns determinats aspectes del llenguatge com són el fonètic i el de la memòria comprensiva a curt termini.

- S'intenta que els aprenentatges siguin com més funcionals millor, és a dir, l'ús de la llengua anglesa no ha de ser una finalitat sinó un vehicle per cantar, jugar, fer activitats manuals, demanar, divertir-se i al mateix temps aprendre a comunicar-se en aquesta llengua. Tot això afavoreix una intensa activitat manipulativa i d'experimentació.

- Les activitats que es porten a terme són el més significatives possible per als nens, dins d'un context proper i també molt lligades als seus interessos.

- També cal tenir en compte i valorar la part afectiva dels alumnes, ja que si s'estableix una bona sin- tonia entre els alumnes i el mestre/a, en les seves expressions, actituds i manifestacions s'establirà i facilitarà la comunicació personal de tots, i per tant, la motivació i l'aprenentatge.

Organització de l'espai i del temps. Recursos didàctics.

El temps que es dedica amb alumnes a la llengua anglesa forma part de les hores de lliure disposició incloses en el currículum de Primària.

El nombre de sessions, tenint en compte les característiques dels/les alumnes, és de dues per setmana, amb una durada aproximada de 30 minuts. D'aquesta manera l'aprenentatge és més efectiu, ja que les sessions no queden massa espaiades i els infants recorden amb més facilitat el que van fent.

Cal tenir present que la llengua anglesa ha de tenir el seu propi punt de referència i s'han de plantejar una sèrie de recursos i materials que ajudin a establir aquest àmbit diferencial:

- La incorporació de recursos que facilitin l'associació d'aquesta llengua amb una situació determinada i la delimitació d'espais per a la realització de les diferents activitats (jocs, cançons, activitats manuals, etc.).

- En relació a l'espai, cal tenir presents les activitats a realitzar per portar-les a terme en l'espai més adient: pati, aula d'idiomes, classe, etc.

\section{Crear un ambient comunicatiu}

És important crear un ambient que afavoreixi la situació d'aprenentatge-comunicació a partir d'hàbits comunicatius, jocs, dramatitzacions, cançons, cantarelles, contes, imatges, utilització de noves tecnologies (cassetes, vídeos, ordinadors, laboratori portàtil...).

Cal tenir present, en relació a l'adquisició d'aquesta primera llengua estrangera, que els nens entenen molt més del que produeixen i s'ha de crear una dinàmica d'intercanvi i de motivació per fer les tasques proposades i utilitzar la llengua a l'aula i també en l'àmbit escolar.

La incorporació d'uns hàbits comunicatius i de treball facilita l'organització de la mateixa activitat de l'aula i dels nens. A la vida quotidiana de l'aula la utilització de la llengua per a les salutacions, acomiadaments, per 


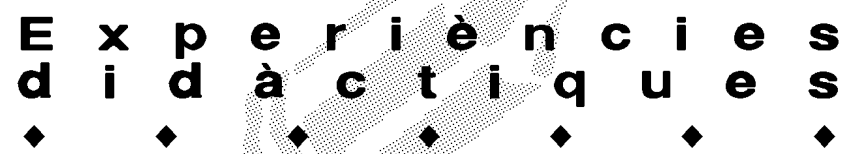

demanar les necessitats més primàries (per anar al wàter, rentar-se les mans...).

Les cançons, les cantarelles, les dramatitzacions, comporten un apropament afectiu i vivencial a les formes culturals de la llengua anglesa. També són un bon recurs per desenvolupar la psicomotricitat, el coneixement i domini del propi cos i el desenvolupament intel-lectual, el treball en equip i altres aspectes de la llengua.

Les imatges ("flashcards", fotocòpies, làmines murals, diapositives, vídeos...) són suports visuals molt necessaris perquè creen diferents contextos i fan que els infants puguin tenir referents d'allò que moltes vegades no és possible observar directament. També ajuden a establir relacions entre la realitat i la seva representació en la llengua anglesa.

L'explicació de contes és un dels recursos més importants, ja que els agrada escoltar històries i participar en el relat. A la vegada que ajuden a desenvolupar la creativitat, la deducció i la fantasia, contribueixen al desenvolupament global dels infants. L'objectiu més important és divertir i interessar el nen/na, al mateix temps que facilita la transmissió de la cultura popular, ajudar a crear l'hàbit d'atenció i, sens dubte, el treball de llenguatge que el conte porta implícit. Quan se'ls ha explicat més d'una vegada, en gaudeixen molt més, i acaben generalment aprenent-lo.

L'aprenentatge del vocabulari es fa d'una forma lúdica i divertida, tenint present que els contes han de ser curts i amb un fil argumental clar.

El vídeo, igual que les imatges -làmines, dibuixos, fotografies - facilita l'apropament a la realitat d'una manera molt més animada i plena de significat per als alumnes. El so del vídeo permet posar en contacte els infants amb altres parlants de llengua anglesa.

El laboratori portàti/permet, per una banda, que els infants rebin una gran quantitat d'input auditiu, i de l'altra, estimula la producció oral, ja que els agrada molt parlar amb un micròfon, enregistrar el que diuen o cantar i després escoltar la seva pròpia gravació. Es pot utilitzar de moltes maneres: tota la classe, en grups —màxim de 6 alumnes-, per parelles o de forma individual. Cal, doncs, tenir

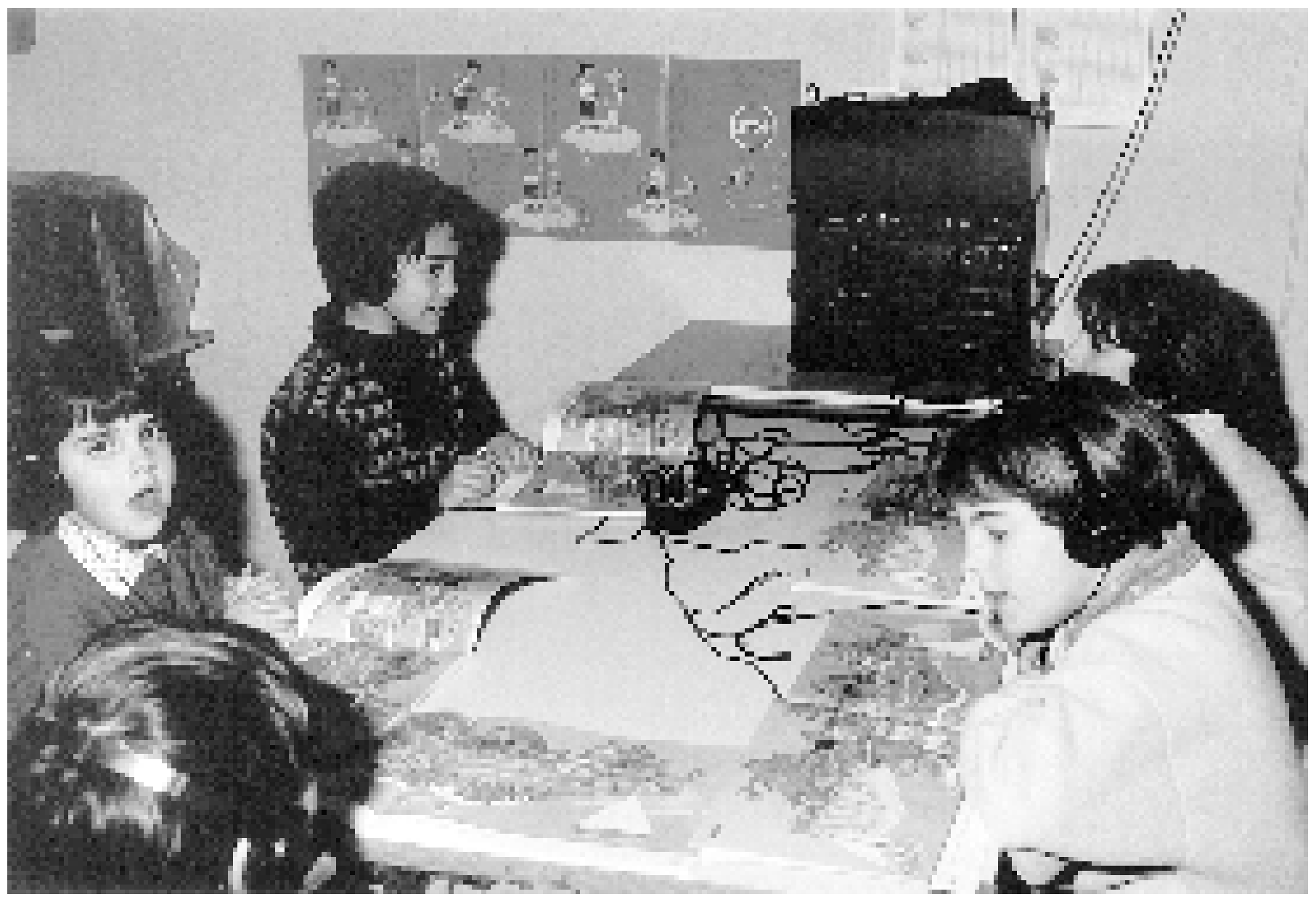




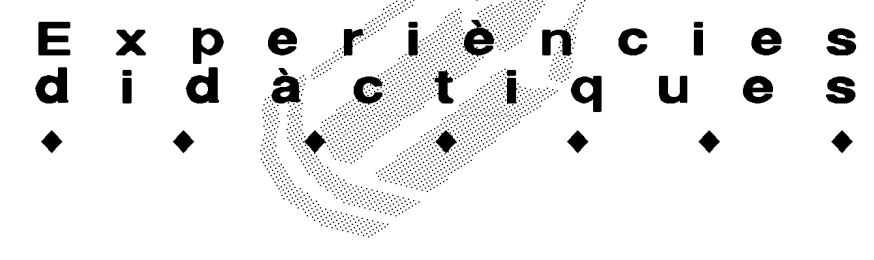

prepararades activitats que responguin a totes aquestes possibilitats.

\section{Eines d'avaluació}

L'avaluació ha d'informar el/la mestre/a sobre el funcionament dels plantejaments metodològics que està aplicant, amb la finalitat d'adequar la seva programació d'acord amb els errors i les dificultats que es vagin detectant durant el procés d'ensenyament/aprenentatge i buscar-ne les solucions.

També l'avaluació ha d'informar els alumnes dels seus progressos en els nous aprenentatges, de les seves aptituds per aprendre, de les seves capacitats intel.lectuals, interessos, motivacions, actituds, etc... També iniciar-los en l'autoavaluació pot ser un element necessari en aquest cicle.

El que interessa avaluar és la competència dels alumnes, l'ús instrumental que fan de la llengua en una situació determinada i no tant els coneixements concrets dels fets de la llengua.

Les activitats d'avaluació han de ser pràctiques $\mathrm{i}$ aplicables fàcilment, coherents amb les activitats que habitualment es fan a l'aula.

S'ha de prioritzar la comprensió oral i les actituds a I'hora d'avaluar, ja que els alumnes d'aquest cicle tenen més possibilitats d'èxit en aquest aspecte que no pas en el d'expressió. Per això aquestes activitats implicaran respostes físiques, dibuixos, ordenació de vinyetes, o respostes molt senzilles de: sí/no, veritable/fals...i no necessàriament de molta producció oral.

\section{El tractament de l'error}

Per a l'adquisició d'una llengua és més efectiu oferir als alumnes el màxim de possibilitats d'escoltar i parlar que no pas de corregir de manera sistemàtica la seva producció, per tal d'evitar la impressió de fracàs que de vegades poden tenir alguns alumnes. Sempre dóna millor resultats valorar les coses que fa bé, l'esforç realitzat, que no pas fer-li veure tot el que fa malament.

També és aconsellable tractar els errors detectats en sessions col-lectives, ja que normalment un mateix error sovint és comès per més d'un alumne.

Una activitat que motiva molt els alumnes és poderse escoltar, mesos més tard, alguna de les seves primeres gravacions i veure com han evolucionat en el procés d'aprenentatge.

S'ha d'entendre l'error com quelcom que forma part del procés d'aprenentatge i cal evitar-ne la valoració negativa. Sense equivocar-se, no s'aprèn cap llengua, per tant, s'ha d'estar disposat a equivocar-se tant com calgui.

En la llengua oral no es poden corregir tots els errors, i el més convenient és exposar als alumnes a enunciats correctes com més sovint millor.

\section{Aspectes/items d'una possible pauta d'avaluació}

A continuació s'indiquen, a títol orientatiu, un seguit de criteris que es poden fer servir per avaluar el treball realitzat a la classe:

- Respon físicament a les ordres habituals de classe.

- Comprèn el sentit global de la narració a partir dels dibuixos, imatges i mímica.

- Reconeix les seqüències d'un conte.

- Dramatitza el conte.

- Respon a preguntes senzilles del conte.

- Reconeix el vocabulari treballat.

- Memoritza la cançó.

- Escolta amb atenció.

- Participa activament en les activitats d'aprenentatge.

- S'esforça en la producció correcta de cantarelles, cançons...

- Utilitza l'ordinador per a la realització de les activitats programades.

- Col-labora amb els seus companys/es.

- Es mostra segur i desinhibit en les activitats orals.

- S'esforça a mantenir l'espai comú net i amb ordre.

- Té cura dels objectes o estris: personals, dels companys/es i de la classe.

- És polit/da en la realització de les activitats.

- Respecta les normes de joc.

\section{Bibliografia consultada}

CRLE. Propostes de llengua oral per a l'ús del laboratori portàtil a l'educació primària. 1995.

CRLE. La llengua estrangera al parvulari i cicle inicial. Orientacions. 1996.

CRLE. Explotació i lectura guiada de contes. 1996.

CRLE. L'avaluació de les llengües estrangeres. 1996.

CRLE. L'aprenentatge de la lectura i de l'escriptura en Ilengües estrangeres. 1996.

GENERALITAT DE CATALUNYA. Departament d'Ensenyament. El tractament de les llengües a l'Educació Primària. 